Nurcahya, I. $\cdot$ Noertjahyani $\cdot$ H. Mulyana

\title{
Pertumbuhan, hasil, dan kandungan kromium kangkung darat akibat kombinasi macam dan dosis bahan organik pada media tanam tercemar
}

\section{Effect of organic fertilizer type and dosage on growth, yield, and chromium content of water spinach in polluted soil}

Diterima : 10 Juli 2019/Disetujui : 22 Desember 2019 / Dipublikasikan : 31 Desember 2019

ODepartment of Crop Science, Padjadjaran University

\begin{abstract}
Water spinach is a heavy metal accumulator plant if grown in polluted soils. This raises the concern of water spinach safety as one of the most consumed vegetables in Asian household. Land pollution in water spinach cultivation area can be caused by industrial activities that involve heavy metals such as tannery. Industrial waste such as chrome leaches to the water system that eventually will be used as irrigation source for agriculture. Organic fertilizer is a potential solution to increase water spinach growth, yield, and absorb heavy metal contaminants. This research evaluated the effect of type and dosage of organic fertilizer on water spinach that grown in chromium-polluted soils. This research design used Randomized Block Design (RBD) with nine treatments and three replication. The treatment of combination of types and dosages of organic fertilizer. There were dried leaves, goat manure, and vermicompost with dosage of $5 \mathrm{t} \mathrm{ha}^{-1}, 10 \mathrm{t} \mathrm{ha} \mathrm{C}^{-1}$ and $15 \mathrm{tha}^{-1}$. The results of this research showed that the effect of combination of organic fertilizer type and dosages at chrome polluted media gave better effect on growth, and yield of water spinach. Giving vermicompost of $15 \mathrm{t} \mathrm{ha}^{-1}$ gaves better effect on plant height, fresh weight of plant, and dry weight of plant, meanwhile the doses of $5 \mathrm{t} \mathrm{ha}^{-1}$ dried leaves showed the lowest chrome content compared to other treatments, but these plants are still unsafe for consumption due to high chrome content.
\end{abstract}

Keywords : Water spinach • Organic fertilizer • Chromium • Yield

\footnotetext{
Dikomunikasikan oleh Anni Yuniarti dan Rija Sudirja

Nurcahya, I. ${ }^{1} \cdot$ Noertjahyani $^{2} \cdot$ H. Mulyana $^{2}$

${ }^{1}$ Fakultas Pertanian Universitas Siliwangi

${ }^{2}$ Fakultas Pertanian Universitas Winaya Mukti

Korespondensi : nurcahya.intan07@gmail.com
}

Sari. Kangkung darat merupakan salah satu tanaman yang dapat menyerap logam berat. Hal ini berkaitan dengan pertumbuhan, hasil, dan keamanan kangkung sebagai bahan konsumsi. Pencemaran lahan pertanian dapat disebabkan dari kegiatan industry, salah satunya yaitu limbah penyamakan kulit yang mengandung logam berat kromium yang mengairi lahan pertanian. Pemberian bahan organik merupakan salah satu cara untuk meningkatkan hasil tanaman kangkung darat dan menyerap logam berat. Penelitian bertujuan untuk mengetahui pengaruh kombinasi macam dan dosis bahan organik pada media tercemar kromium penyamakan kulit terhadap pertumbuhan, hasil dan kandungan kromium pada tanaman kangkung darat. Penelitian ini menggunakan Rancangan Acak Kelompok (RAK) dengan sembilan perlakuan dan tiga kali ulangan. Perlakuan kombinasi macam dan dosis bahan organik terdiri dari serasah daun, pupuk kandang kambing, dan kascing dengan dosis masing-masing $5 \mathrm{t} \mathrm{ha}^{-1}, 10 \mathrm{tha}^{-1}$ dan $15 \mathrm{t} \mathrm{ha}^{-1}$. Hasil penelitian menunjukkan bahwa perlakuan kombinasi macam dan dosis bahan organik pada media tercemar kromium penyamakan kulit berpengaruh nyata terhadap pertumbuhan, dan hasil tanaman kangkung darat. Kombinasi kascing $15 \mathrm{t} \mathrm{ha}^{-1}$ memberikan pengaruh yang lebih baik terhadap tinggi tanaman, bobot segar per tanaman, dan bobot kering per tanaman, sedangkan pemberian serasah daun $5 \mathrm{t} \mathrm{ha}^{-1}$ menghasilkan tanaman kangkung darat dengan kandungan kromium yang lebih rendah (51,33 $\mathrm{mgkg}^{-1}$ ) dibandingkan perlakuan lainnya tetapi tanaman dengan kadar tersebut belum aman untuk dikonsumsi.

Kata kunci : Kangkung darat - Bahan organik . Kromium · Hasil 


\section{Pendahuluan}

Perhatian masyarakat dan pemerintah pada sektor pertanian tidak hanya dilihat dari segi peningkatan produksi dan kualitas yang diperoleh, tetapi juga perlu ditunjang dengan keamanan pangan. Keamanan pangan berkaitan dengan pencemaran lingkungan. Salah satu penyebab pencemaran lingkungan yaitu akumulasi logam berat yang sangat tinggi pada tanah. Tingginya logam berat dalam tanah tidak hanya meracuni tanaman dan makhluk hidup lainnya tetapi juga menyebabkan pencemaran terhadap lingkungan (Siahaan et al., 2014). Stres tanaman yang diakibatkan oleh logam berat tiga kali lebih besar daripada yang disebabkan oleh pestisida (Jeliazko, 2001).

Tanaman sayuran merupakan salah satu tanaman hortikultura yang dapat menyerap logam berat. Sayuran yang mengandung logam berat bila dikonsumsi oleh manusiaakan masuk ke dalam tubuh manusia seperti timbal, kromium, kadmium, dan seng (Sari et al., 2011). Salah satu tanaman sayuran yang dapat menyerap dan mengakumulasikan logam berat di dalam jaringan tanaman adalah tanaman kangkung (Balai Penelitian Lingkungan Pertanian, 2013). Adanya logam berat pada tanah juga dapat menyebabkan produktivitas kangkung menurun (Budihani, 2009).

Tersedianya bahan organik dalam tanah selain dapat digunakan oleh mikroorganisme sebagai sumber energi, juga dapat bereaksi dengan logam berat membentuk senyawa kompleks sehingga dapat mengurangi sifat racun logam berat (Stevenson, 1994). Pupuk organik kompos melalui substansi humus yang dikandungnya dan kemampuan tukar kation, mampu bereaksi dengan ion logam membentuk senyawa kompleks serta khelat, sehingga ion logam sulit untuk bebas (Simanungkalit, et al., 2006; Hermana dan Nurhayati, 2010). Kompos mampu menurunkan (> 87\%) kandungan logam berat di air (Prasetyono, 2015).

Pupuk organik dapat menambah unsur hara makro dan mikro dalam tanah, memperbaiki struktur tanah, menambah kehidupan jasad renik dalam tanah dan sebagai sumber zat makanan bagi tanaman (Lingga dan Marsono, 2008). Menurut Kucasov dan Guvener (2009) pemberian kompos dapat digunakan untuk mengurangi logam berat.
Lahan pertanian di Copong-Sukaregang, Kabupaten Garut, telah tercemar limbah penyamakan kulit. Berdasarkan hasil penelitian Dimyati (2006), limbah industri penyamakan kulit di Sukaregang, Kabupaten Garut, mempengaruhi produktivitas usaha tani padi sawah hingga $37 \%$. Penambahan bahan organik pada tanaman jagung dapat menurunkan kandungan kromium pada tanah tercemar limbah industri tekstil batik (Widyastuti, et al., 2003). Penambahan pupuk kompos dapat meningkatkan pertumbuhan tinggi, diameter dan biomassa semai mindi pada media tambang emas Pongkor (Setyaningsih, 2007).

Berdasarkan uraian di atas, maka perlu dilakukan penelitian untuk mengetahui pengaruh macam dan dosis bahan organik pada media tanam tercemar kromium dari penyamakan kulit. Bahan organik yang diberikan dapat menyediakan bahan organik yang berfungsi sebagai khelat untuk menjerap logam berat kromium yang berada di dalam tanah sehingga mengurangi serapan kromium oleh tanaman kangkung darat. Bahan organik ini juga diharapkan dapat menyediakan unsur hara yang dibutuhkan untuk meningkatkan pertumbuhan dan hasil tanaman.

\section{Bahan dan Metode}

Penelitian ini bersifat verifikatif yang dilakukan melalui pendekatan eksperimen. Percobaan dilakukan di Cileunyi, Kabupaten Bandung, dengan menggunakan tanah yang diambil dari Copong-Sukaregang, Kabupaten Garut, dengan ordo tanah Andisol dan bertekstur lempung berpasir. Media tanah yang digunakan diambil dari daerah sekitar penyamakan kulit, berjarak 3-4 km dari tempat pembuangan limbah. Hasil analisis tanah awal terkandung unsur kromium (Cr) sebesar $345 \mathrm{mg} \mathrm{kg}^{-1}$ dan dikategorikan melebihi ambang batas, yaitu 2,5 mg kg-1 (Djunaedi (2004) dalam Hartati, et al., (2014)). Bahan-bahan lainnya yang digunakan pada percobaan ini antara lain, benih kangkung darat Bangkok LP-1, bahan organik (serasah daun, pupuk kandang kambing dan kascing) dan pestisida nabati. Alat-alat yang diperlukan antara lain, wadah media tanam berukuran 36 $\mathrm{cm} \times 28 \mathrm{~cm}$, tali rapia, label, timbangan, cangkul, serta sprayer.

Percobaan menggunakan Rancangan Acak Kelompok (RAK) dengan sembilan perlakuan

Nurcahya, I. dkk.: Pertumbuhan, hasil, dan kandungan kromium kangkung darat akibat kombinasi macam dan dosis bahan organik pada media tanam tercemar 
kombinasi macam dan dosis bahan organik, yaitu (A) Serasah daun $5 \mathrm{t} \mathrm{ha}^{-1}$, (B) Serasah daun $10 \mathrm{t} \mathrm{ha}^{-1}$, (C) Serasah daun $15 \mathrm{t} \mathrm{ha}^{-1}$, (D) Pupuk kandang kambing $5 \mathrm{t} \mathrm{ha}^{-1}$, (E) Pupuk kandang kambing $10 \mathrm{t} \mathrm{ha}^{-1}$, (F) Pupuk kandang kambing $15 \mathrm{t} \mathrm{ha}^{-1}$, (G) Kascing $5 \mathrm{t} \mathrm{ha}^{-1}$, (H) Kascing $10 \mathrm{t}$ ha $^{-1}$, dan (I) Kascing $15 \mathrm{t} \mathrm{ha}^{-1}$. Tiap perlakuan diulang tiga kali, sehingga terdapat 27 unit satuan percobaan. Setiap unit percobaan terdiri dari 2 wadah/bak media tanam.

Respons tanaman kangkung akibat perlakuan meliputi tinggi tanaman, jumlah daun, bobot segar tanaman, bobot kering tanaman, dan kandungan kromium pada tanaman. Pengujian apakah terdapat perbedaan signifikan antar perlakuan diuji dengan uji Fisher pada taraf nyata $5 \%$ dan untuk mengetahui perbedaan masing-masing perlakuan menggunakan DMRT (Duncan's Multiple Range Test) pada taraf nyata $5 \%$.

Media tanam berupa tanah diambil dari lahan di Copong-Sukaregang, Kabupaten Garut, yang berjarak 3-4 km dari pembuangan limbah pada lapisan tanah top soil dengan kedalaman 20-30 cm kemudian semua tanah tersebut dicampurkan hingga rata agar homogen kemudian diayak dengan ayakan. Setelah itu, diambil sampel tanah sebanyak $2 \mathrm{~kg}$ untuk dianalisis kandungan kromiumnya. Untuk persiapan media tanam, tanah yang telah dicampur dan diayak tadi dimasukkan ke dalam wadah/bak media tanam berukuran $36 \mathrm{~cm} \times 28$ $\mathrm{cm}$ sampai setinggi $10 \mathrm{~cm}$ kemudian dicampur merata dengan bahan organik sesuai dengan perlakuan kombinasi macam dan dosis bahan organik. Penanaman benih kangkung berjarak tanam $9 \mathrm{~cm} \times 14 \mathrm{~cm}$. Benih ditanam sebanyak 2 butir benih per lubang tanam.

Pemeliharaan tanaman seperti penyulaman, penyiraman, dan pengendalian organisme pengganggu tanaman dilakukan sesuai teknik budidaya kangkung darat. Panen dilakukan pada umur 35 hari setelah tanam pada sore hari.

\section{Hasil dan Pembahasan}

Hasil analisis kimia bahan organik meliputi: unsur hara, $\mathrm{C} / \mathrm{N}$ ratio dan $\mathrm{pH}$ pada bahan organik serasah daun, pupuk kandang kambing dan kascing diperoleh dari data sekunder. Serasah daun mengandung unsur $0,44 \% \mathrm{~N}, 0,03$ $\% \mathrm{P}, 0,04 \% \mathrm{~K}, \mathrm{C} / \mathrm{N}$ ratio 18 dan $\mathrm{pH} 8,07$ (Wahyudi, et al., 2013). Pupuk kandang kambing mengandung unsur 2,95\% N, 0,12\% P, 1,76 \% $\mathrm{K}, \mathrm{C} / \mathrm{N}$ ratio 11 dan $\mathrm{pH}$ 7,53 (Putra, 2013). Kascing mengandung unsur 1,58 \% N, 0,07 \% P, $0,85 \% \mathrm{~K}, \mathrm{C} / \mathrm{N}$ ratio 13 dan $\mathrm{pH}$ 7,40 (Sudiarto, 2013).

Tabel 1. Tinggi tanaman kangkung darat akibat kombinasi macam dan dosis bahan organik pada media tanam tercemar kromium penyamakan kulit.

\begin{tabular}{|c|c|c|c|c|}
\hline \multirow{2}{*}{$\begin{array}{l}\text { Perla- } \\
\text { kuan }\end{array}$} & \multicolumn{4}{|c|}{ Rata-Rata Tinggi Tanaman $(\mathrm{cm})$} \\
\hline & $14 \mathrm{HST}$ & $21 \mathrm{HST}$ & 28HST & $35 \mathrm{HST}$ \\
\hline $\mathrm{A}$ & $9,91 \mathrm{ab}$ & $14,22 \mathrm{abc}$ & $16,86 \mathrm{a}$ & $19,28 \mathrm{a}$ \\
\hline B & $10,07 \mathrm{ab}$ & $14,41 \mathrm{abc}$ & $17,80 \mathrm{a}$ & $20,42 \mathrm{a}$ \\
\hline C & $10,32 \mathrm{abc}$ & 14,97 bc & $17,51 \mathrm{a}$ & $20,77 \mathrm{a}$ \\
\hline $\mathrm{D}$ & $10,47 \mathrm{abc}$ & $13,93 \mathrm{ab}$ & $17,19 \mathrm{a}$ & $20,27 \mathrm{a}$ \\
\hline $\mathrm{E}$ & $9,96 \mathrm{ab}$ & $14,26 \mathrm{abc}$ & $16,45 \mathrm{a}$ & $20,03 \mathrm{a}$ \\
\hline $\mathrm{F}$ & $9,22 \mathrm{a}$ & 13,44 & $16,68 \mathrm{a}$ & $20,73 \mathrm{a}$ \\
\hline G & $11,57 \mathrm{bc}$ & $15,25 \mathrm{~cd}$ & $17,89 \mathrm{a}$ & $20,45 a$ \\
\hline $\mathrm{H}$ & $11,58 \mathrm{bc}$ & $15,19 \mathrm{~cd}$ & $18,32 \mathrm{a}$ & $20,85 \mathrm{a}$ \\
\hline I & $11,88 \quad \mathrm{c}$ & $16,23 \mathrm{~d}$ & $18,39 \mathrm{a}$ & $21,27 \mathrm{a}$ \\
\hline
\end{tabular}

Keterangan : Angka yang diikuti dengan huruf yang sama pada kolom yang sama menunjukkan tidak berbeda nyata menurut Uji Jarak Berganda Duncan pada taraf nyata $5 \%$

Tabel 2. Jumlah daun kangkung darat akibat kombinasi macam dan dosis bahan organik pada media tanam tercemar kromium penyamakan kulit.

\begin{tabular}{|c|c|c|c|c|}
\hline \multirow{2}{*}{$\begin{array}{l}\text { Perla- } \\
\text { kuan }\end{array}$} & \multicolumn{4}{|c|}{ Rata-rata jumlah daun (helai) } \\
\hline & $\begin{array}{c}14 \\
\text { HST }\end{array}$ & 21HST & $28 \mathrm{HST}$ & 35 HST \\
\hline A & $3,59 a$ & $6,42 \mathrm{a}$ & 8,17 a & $11,42 \mathrm{ab}$ \\
\hline B & $3,88 \mathrm{a}$ & $6,84 \mathrm{a}$ & $8,83 \mathrm{ab}$ & $11,29 a b$ \\
\hline $\mathrm{C}$ & $3,96 \mathrm{a}$ & $6,71 \mathrm{a}$ & $9,84 \mathrm{ab}$ & 10,83 a \\
\hline D & $3,75 \mathrm{a}$ & $6,63 a$ & 9,79 a & 10,85 a \\
\hline $\mathrm{E}$ & $3,92 \mathrm{a}$ & $6,33 \mathrm{a}$ & $9,63 \mathrm{ab}$ & 10,79 a \\
\hline $\mathrm{F}$ & $3,63 \mathrm{a}$ & $6,75 a$ & $9,04 \mathrm{ab}$ & 10,38 a \\
\hline G & $4,00 \mathrm{a}$ & $7,46 a$ & $9,96 \quad b$ & $11,17 \mathrm{ab}$ \\
\hline $\mathrm{H}$ & $4,09 \mathrm{a}$ & $8,17 \mathrm{a}$ & $10,29 \mathrm{~b}$ & $11,38 \mathrm{ab}$ \\
\hline I & $4,34 \mathrm{a}$ & $7,46 \mathrm{a}$ & $10,42 \mathrm{~b}$ & $12,20 \mathrm{~b}$ \\
\hline
\end{tabular}

Keterangan : Angka yang diikuti dengan huruf yang sama menunjukkan tidak berbeda nyata menurut Uji Jarak Berganda Duncan pada taraf nyata $5 \%$

Tinggi Tanaman. Tabel 1 menunjukkan aplikasi macam dan dosis bahan organik memberikan efek berbeda terhadap tinggi tanaman kangkung darat yang ditanam pada media tercemar $\mathrm{Cr}$ pada umur 14 dan 21 hari setelah tanam (HST). Bahan organik kascing dapat memberikan tinggi tanaman kangkung darat lebih tinggi dibandingkan dengan pupuk kandang kambing dan serasah daun. Tinggi 
tanaman kangkung darat pada umur 28 HST dan 35 HST tidak menunjukkan variasi yang nyata akibat pemberian macam dan dosis bahan organik.

Jumlah Daun. Tabel 2 menunjukkan akibat kombinasi macam dan dosis bahan organik pada media tanam tercemar kromium penyamakan kulit tidak berbeda nyata terhadap jumlah daun pada umur 14 HST dan 21 HST. Pada umur 28 HST dan 35 HST walaupun antar perlakuan tidak berbeda nyata namun pemberian kascing memiliki jumlah daun yang lebih banyak dibandingkan dengan yang diberi pupuk kandang kambing dan serasah daun.

Tabel 3. Bobot segar dan bobot kering kangkung darat akibat kombinasi macam dan dosis bahan organik pada media tanam tercemar kromium penyamakan kulit.

\begin{tabular}{ccc}
\hline \multirow{2}{*}{ Perlakuan } & \multicolumn{3}{c}{ Rata-rata } \\
\cline { 2 - 3 } & $\begin{array}{c}\text { Bobot segar } \\
\text { per tanaman }(\mathrm{g})\end{array}$ & $\begin{array}{c}\text { Bobot kering } \\
\text { per tanaman }(\mathrm{g})\end{array}$ \\
\hline $\mathrm{A}$ & $2,46 \mathrm{a}$ & $0,44 \mathrm{bc}$ \\
$\mathrm{B}$ & $2,60 \mathrm{a}$ & $0,39 \mathrm{abc}$ \\
$\mathrm{C}$ & $2,53 \mathrm{ab}$ & $0,39 \mathrm{abc}$ \\
$\mathrm{D}$ & $2,60 \mathrm{ab}$ & $0,37 \mathrm{ab}$ \\
E & $2,49 \mathrm{ab}$ & $0,37 \mathrm{ab}$ \\
F & $2,39 \mathrm{a}$ & $0,30 \mathrm{a}$ \\
$\mathrm{G}$ & $3,14 \mathrm{abc}$ & $0,45 \mathrm{bc}$ \\
$\mathrm{H}$ & $3,29 \mathrm{bc}$ & $0,53 \mathrm{~cd}$ \\
I & $3,74 \mathrm{c}$ & $0,62 \mathrm{~d}$ \\
\hline
\end{tabular}

Keterangan : Angka yang diikuti dengan huruf yang sama tidak berbeda nyata menurut Uji Jarak Berganda Duncan pada taraf nyata $5 \%$

Bobot Segar dan Bobot Kering per Tanaman. Tabel 3 menunjukkan bahwa akibat kombinasi macam dan dosis bahan organik pada media tanam tercemar $\mathrm{Cr}$ penyamakan kulit memberikan bobot segar dan bobot kering per tanaman yang bervariasi. Hasil bobot segar dan bobot kering per tanaman lebih baik bila diberi kascing (5 t ha-1, $10 \mathrm{t} \mathrm{ha}^{-1}$ dan $15 \mathrm{t}$ ha $^{-1}$ ) dibandingkan dengan pemberian serasah daun dan pupuk kandang kambing. Bobot segar dan bobot kering tanaman yang diberi bahan organik serasah daun dan pupuk kandang kambing dengan dosis yang meningkat cenderung menurun. Hal ini tidak terjadi pada tanaman kangkung darat yang diberi kascing.

Kandungan Kromium. Tabel 4 menunjukkan bahwa akibat kombinasi macam dan dosis bahan organik pada media tanam tercemar $\mathrm{Cr}$ penyamakan kulit memberikan kandungan $\mathrm{Cr}$ yang tidak berbeda antar perlakuan namun kandungan kromium pada tanaman kangkung darat yang diberi pupuk kandang kambing menunjukkan kandungan kromium yang lebih tinggi dibandingkan dengan pemberian bahan organik serasah daun dan kascing.

Tabel 4. Kandungan kromium kangkung darat akibat kombinasi macam dan dosis bahan organik pada media tanam tercemar kromium penyamakan kulit.

\begin{tabular}{cc}
\hline Perlakuan & $\begin{array}{c}\text { Rata-rata kandungan } \mathrm{Cr} \\
\text { tanaman }\left(\mathrm{mgkg}^{-1}\right)\end{array}$ \\
\hline A & $51,33 \mathrm{a}$ \\
B & $57,67 \mathrm{ab}$ \\
C & $76,33 \mathrm{abc}$ \\
D & $107,33 \mathrm{bc}$ \\
E & $119,33 \mathrm{c}$ \\
F & $104,67 \mathrm{bc}$ \\
G & $73,67 \mathrm{abc}$ \\
H & $60,00 \mathrm{ab}$ \\
I & $88,67 \mathrm{abc}$ \\
\hline
\end{tabular}

Keterangan : Angka yang diikuti dengan huruf yang sama menunjukkan tidak berbeda nyata menurut Uji Jarak Berganda Duncan pada taraf $5 \%$

Aplikasi kombinasi macam dan dosis bahan organik memberikan pengaruh yang berbeda nyata terhadap pertumbuhan dan hasil tanaman kangkung darat. Untuk kandungan kromium walaupun antar perlakuan tidak berbeda nyata namun terdapat perlakuan yang lebih baik dari perlakuan lainnya. Berdasarkan hasil penelitian menunjukkan bahwa perlakuan kascing $15 \mathrm{t} \mathrm{ha}^{-1}$ (I) dapat meningkatkan tinggi tanaman, jumlah daun, bobot basah per tanaman dan bobot kering per tanaman tetapi perlakuan pupuk kandang kambing $15 \mathrm{t}^{\mathrm{a}} \mathrm{a}^{-1}(\mathrm{~F})$ menunjukkan pertumbuhan dan hasil kangkung darat yang terhambat. Perlakuan A (serasah daun $5 \mathrm{t} \mathrm{ha}^{-1}$ ) mampu menurunkan kandungan kromium yang diserap oleh tanaman kangkung darat.

Pemberian kascing $15 \mathrm{t} \mathrm{ha}^{-1}$ (I) mampu memberikan pengaruh terhadap tinggi tanaman kangkung darat dibandingkan dengan perlakuan serasah daun dan pupuk kandang kambing. Hal ini diduga karena kascing sudah terdekomposisi secara optimal dan memiliki $\mathrm{C} / \mathrm{N}$ ratio 13 yang hampir mendekati $\mathrm{C} / \mathrm{N}$ ratio tanah 12-15 (Novizan, 2005), sedangkan pupuk kandang kambing dan serasah daun kemungkinan sudah terdekomposisi namun belum maksimal. Pemberian kascing $5 \mathrm{t} \mathrm{ha}^{-1}(\mathrm{G})$ dan kascing $10 \mathrm{t} \mathrm{ha}^{-1}(\mathrm{H})$ belum menunjukkan perbedaan nyata karena dosis tersebut masih 
belum mencukupi dalam pertumbuhan tinggi tanaman kangkung darat. Tinggi tanaman pada umur 28-35 HST tidak menunjukkan perbedaan nyata karena tanaman kangkung darat sudah mendapat unsur hara cukup dan akan menuju fase pertumbuhan akhir.

Jumlah daun pada tanaman kangkung darat pada umur 14 HST dan 21 HST menunjukkan tidak adanya perbedaan yang nyata karena unsur hara yang diserap sedang digunakan untuk fase pertumbuhan awal, salah satunya adalah tinggi tanaman. Pada umur 28 HST dan 35 HST, antar perlakuan juga tidak menunjukkan perbedaan yang nyata pada jumlah daun, namun pemberian kascing $15 \mathrm{t} \mathrm{ha}^{-1}$ (I) menunjukkan pengaruh lebih baik dibandingkan dengan serasah daun. Unsur hara pada perlakuan kascing dapat mencukupi dalam merangsang pertumbuhan karena kandungan unsur $\mathrm{N}$ pada kascing lebih besar $(1,58 \%)$ dibandingkan dengan serasah daun $(0,44 \%)$. Pupuk kandang kambing walaupun memiliki unsur $\mathrm{N}$ yang tinggi tetapi masih terdapat tekstur butiran. Menurut Widowati (2004), tekstur pupuk berupa butiran agak sukar pecah secara fisik sehingga lambat terdekomposisi dan menyebabkan unsur hara kurang dapat diserap tanaman. Pada umur 35 HST perlakuan kascing $15 \mathrm{t} \quad \mathrm{ha}^{-1}$ (I) menunjukkan pengaruh lebih baik walaupun tanaman kangkung darat akan menuju fase pertumbuhan akhir namun tunas masih terus bertambah sejalan dengan penambahan jumlah daun sehingga masih diperlukan unsur hara. Menurut Harjadi (2002), adanya kebutuhan unsur hara dibutuhkan dalam pembentukan klorofil yang bermanfaat untuk fotosintesis daun.

Pemberian kascing $15 \mathrm{t} \mathrm{ha}^{-1}$ (I) berpengaruh terhadap bobot segar per tanaman dan bobot kering per tanaman kangkung darat karena mampu meningkatkan hasil fotosintesis dan translokasi karbohidrat untuk membentuk bahan segar dan mampu memenuhi kebutuhan tanaman kangkung pada proses fotosintesis yang akan mengakumulasi bobot kering tanaman kangkung darat. Unsur hara makro dan mikro yang cukup akan mendukung proses fotosintesis yang menghasilkan banyaknya fotosintat yang terbentuk yang mendukung hasil tanaman (Harjadi, 2002).

Kandungan $\mathrm{Cr}$ tanaman kangkung yang diberi pupuk kandang kambing paling tinggi dibandingkan perlakuan lain. Hal ini diduga karena pada perlakuan pupuk kandang kambing, tanaman masih lebih cepat dalam menyerap $\mathrm{Cr}$ dalam tanah karena belum maksimalnya sintesis senyawa khelat yang berperan dalam proses penguraian untuk menjadi unsur-unsur yang dibutuhkan oleh tanaman. Menurut Nurjaya, et al. (2006), proses penurunan jerapan logam dengan bahan organik melalui gugus karboksil bermuatan negatif yang akan mengikat logam membentuk khelat sehingga tidak dapat diserap tanaman. Hal yang sama terjadi pada amelioran zeolit yang memiliki muatan negatif dan strukturnya mampu mengadsorpsi logam-logam berat yang bermuatan positif (Noertjahyani dan Sondari, 2009).

Pada perlakuan pupuk kandang kambing, kandungan kromium lebih tinggi dibandingkan dengan serasah daun dan kascing, hal ini menyebabkan pula tinggi tanaman, jumlah daun, bobot segar dan bobot kering tanaman umumnya lebih rendah. Menurut Panda dan Choudhary (2005) kandungan kromium pada tanaman dapat mengakibatkan terjadinya hambatan pertumbuhan, menginduksi klorosis pada daun muda, mengurangi kandungan pigmen, menghambat aktivitas enzim, merusak sel akar, dan menyebabkan modifikasi struktur pada kloroplas dan membran sel.

Pemberian serasah daun $5 \mathrm{t} \mathrm{ha}^{-1}$ (A) memberikan kandungan kromium yang lebih rendah dibandingkan perlakuan pupuk kandang kambing. Hal ini disebabkan oleh $\mathrm{pH}$ serasah daun yang mencapai 8,07 yang dapat meningkatkan $\mathrm{pH}$ tanah sehingga dapat menyediakan unsur $\mathrm{P}$ yang menjerap logam dengan baik. Ketersediaan $\mathrm{P}$ dalam tanah dapat ditingkatkan dengan penambahan bahan organik yang salah satunya melalui senyawa pengkelat hasil dekomposisi yang menyebabkan terjadinya pelepasan fosfat yang berikatan dengan logam tidak larut menjadi bentuk terlarut (Stevenson, 1994). Hal ini pun sejalan dengan pemberian kascing yang membantu pembentukan khelat yang akan menjerap logam berat melalui peningkatan $\mathrm{P}$ tersedia sehingga tanaman kangkung darat menunjukkan pertumbuhan dan hasil yang lebih baik. Pemberian serasah daun $5 \mathrm{t} \mathrm{ha}^{-1}$ (A) memberikan hasil tanaman kangkung darat yang mengandung logam kromium lebih rendah sebesar 51,33 mgkg-1 $^{-1}$ namun masih lebih tinggi dibandingkan ambang batas cemaran logam kromium untuk tanaman 5-30 $\mathrm{mg} \mathrm{kg}^{-1}$ dan 
ambang batas maksimum cemaran kromium untuk konsumsi 0,4 mg kg-1 (Djunaedi (2004) dalam Hartati et al., (2014)).

Berdasarkan hasil di atas, pemberian serasah daun dan pupuk kandang kambing masih belum dapat mengoptimalkan pertumbuhan dan hasil tanaman kangkung darat serta belum mampu mengurangi kandungan $\mathrm{Cr}$ sampai di bawah ambang batas cemaran $\mathrm{Cr}$, oleh karena itu selanjutnya perlu dilakukan penambahan dosis kascing yang memadai dan tentunya sampai dengan beberapa kali musim tanam untuk dapat mengoptimalkan produksi tanaman kangkung darat dan mengurangi kandungan kromium.

\section{Kesimpulan}

Berdasarkan analisis data dan pembahasan dapat disimpulkan bahwa pertumbuhan, hasil dan kandungan kromium tanaman kangkung darat pada media tanam tercemar kromium penyamakan kulit dipengaruhi oleh kombinasi macam dan dosis bahan organik. Aplikasi kombinasi kascing $15 \quad \mathrm{t}$ ha $^{-1}$ memberikan pengaruh yang lebih baik terhadap tinggi tanaman, bobot segar per tanaman dan bobot kering per tanaman kangkung darat sedangkan kombinasi serasah daun $5 \mathrm{t} \mathrm{ha}^{-1}$ memberikan tanaman kangkung darat dengan kandungan kromium lebih rendah (51,33 mg $\left.\mathrm{kg}^{-1}\right)$ dibandingkan dengan perlakuan lainnya tetapi masih belum aman untuk dikonsumsi.

\section{Daftar Pustaka}

Balai Penelitian Lingkungan Pertanian. 2013. Teknologi praktis untuk mengurangi pencemaran logam berat. Dalam http:// balingtan.litbang.pertanian.go.id/in d/index.php/berita/141-teknologi-praktisuntuk-mengurangi-pencemaran-logamberat. Diakses 26 November 2019.

Budihani, K. 2009. Dampak lumpur lapindo terhadap pertumbuhan dan kualitas kangkung (Ipomoea reptans). Fakultas Pertanian Universitas Brawijaya.

Dimyati, A. 2006. Dampak limbah industi kulit bagi kegiatan usaha tani padi sawah (kasus di Kecamatan Garut Kota dan Kecamatan Karangpawitan Kabupaten Garut). Magis- ter Agribisnis Program Pascasarjana Universitas Winaya Mukti.

Harjadi, S.S. 2002. Pengantar Agronomi Cetakan XVII. Gramedia. Jakarta.

Hartati, S., J. Syamsiah, dan E. Erniasita. 2014. Imbangan paitan (Tithonia diversifolia) dan pupuk phonska terhadap kandungan logam berat $\mathrm{Cr}$ pada tanah sawah. Jurnal Ilmu Tanah dan Agroklimatologi, 11 (1): 21-28.

Hermana, J. dan E. Nurhayati. 2010. Removal of $\mathrm{Cr}^{3+}$ dan $\mathrm{Hg}^{2+}$ using compost derived from municipal solid waste. Sustain. Environ. Res. 20: 257-261.

Jeliazko, V.D. 2001. Study on heavy metals absorption by plants. Dalam https:// scholarworks.umass.edu/dissertations/AA I3012144/. Diakses 26 November 2019.

Kucasov, G., and Z. Guvener. 2009. Efficiency of compost in the removal of heavy metals from the industrial waste water. Environ Geol. 57: 291-296.

Lingga, P., dan Marsono. 2008. Petunjuk Penggunaan Pupuk. Penebar Swadaya. Jakarta.

Noertjahyani dan N. Sondari. 2009. Efek takaran zeolit terhadap pertumbuhan kadar kadmium pupus dan hasil tanaman selada (Lactuca sativa L.) pada cekaman logam berat kadmium. J. Zeolit Indonesia, 8 (2): 76-82.

Novizan. 2005. Petunjuk Pemupukan yang Efektif. Agro Media Pustaka. Jakarta.

Nurjaya, E. Zihan dan M.S. Saeni. 2006. Pengaruh amelioran terhadap kadar $\mathrm{Pb}$ tanah, serapannya serta hasil tanaman bawang merah pada Inceptisols. Jurnal Ilmu-Ilmu Pertanian Indonesia, 8 (2): 110-119.

Panda, S.K., and S. Choudhury. 2005. Chromium stress in plants. Brazilian Journal of Plant Physiology, 17 (1): 95-102

Prasetyono, E. 2015. Kemampuan kompos dalam menurunkan kandungan logam berat timbal $(\mathrm{Pb})$ pada media budidaya ikan. Jurnal Akuatika, VI (1): 21-29

Putra. 2013. Pupuk Organik Kambing Etawa. Leaflet. Putra Sariwangi. Tasikmalaya.

Sari, A.D., T.R. Pardede, dan F.R. Harun. 2011. Analisis kandungan timbal $(\mathrm{Pb})$ dan cadmium (Cd) pada kangkung air (Ipomoea aquatica Forssk) dan kangkung darat (Ipomoea reptans Poir) di daerah Mabar-Kim secara spektofotometri serapan atom. Dalam http://repository.usu.ac.id/handle/1234567 89/28467. Diakses 26 November 2019. 
Setyaningsih, L. 2007. Pemanfaatan cendawan mikoriza arbuskula dan kompos aktif untuk meningkatkan pertumbuhan semai mindi (Melia azedarach Linn) pada media tailing tambang emas Pongkor. Pascasarjana Institut Pertanian Bogor.

Siahaan, B.C., S.R. Utami, dan E. Handayanto. 2014. Fitoremediasi tanah tercemar merkuri menggunakan Lindernia crustacea, Digitaria radicosaa dan Cyperus rotundus serta pengaruhnya terhadap pertumbuhan dan produksi tanaman jagung. Jurnal Tanah dan Sumberdaya Lahan, 1 (2): 38-48.

Simanungkalit, R.D.M., D.A. Suriadikarta, R. Saraswati, D. Setyorini, dan W. Hartatik. 2006. Pupuk Organik dan Pupuk Hayati. Balai Besar Litbang Sumberdaya Lahan Pertanian Badan Penelitian dan Pengembangan Pertanian. Bogor.

Stevenson, F.J. 1994. Humus Chemistry : Genesis,
Composition, Reactions (Second Edition). John Wiley and Sons Inc. New York.

Sudiarto, B. 2013. Potensi, Efisiensi dan Standarisasi Penggunaan Pupuk Organik Kascing (Vermicompost) dalam Meningkatkan Produktivitas Pertanian. Leaflet. Osa Perdana. Bandung.

Wahyudi, Ade, dan Prasetyo. 2013. Daun Cakra. Leaflet. Cakra Mandiri Pratama Indonesia. Bandung.

Widowati, L. 2004. Pupuk Organik dan Pupuk Hayati. Agromedia Pustaka. Jakarta.

Widyastuti, E.R., R. Rosarastuti dan J. Syamsiyah. 2003. Pengaruh macam bahan organik terhadap kelarutan dan kadar $\mathrm{Cr}$ tanaman jagung (Zea mays L.) di tanah Entisols yang tercemar limbah cair industri tekstil batik. Prosiding Seminar Nasional Pengelolaan Lingkungan Pertanian Buku I : Kumpulan Makalah : 335-350. 